\title{
Correction to: Two new species of threadlike blood flukes (Aporocotylidae), with a molecular revision of the genera Ankistromeces Nolan \& Cribb, 2004 and Phthinomita Nolan \& Cribb, 2006
}

\author{
S. C. Cutmore $(1)$ R. Q.-Y. Yong - J. D. Reimer - S. Shirakashi •
}

M. J. Nolan • T. H. Cribb

Published online: 27 September 2021

(C) Springer Nature B.V. 2021

\section{Correction to: Syst Parasitol \\ https://doi.org/10.1007/s11230-021-10002-8}

The original version of this article contained several typos and mistakes, because the proof corrections were not carried out by the publisher. The original article has been corrected.

Publisher's Note Springer Nature remains neutral with regard to jurisdictional claims in published maps and institutional affiliations.

The original article can be found online at https:// doi.org/10.1007/s11230-021-10002-8.

S. C. Cutmore $(\bowtie) \cdot$ R. Q.-Y. Yong - T. H. Cribb School of Biological Sciences, The University of Queensland, Brisbane, QLD 4072, Australia e-mail: scott.cutmore@uqconnect.edu.au

J. D. Reimer

Molecular Invertebrate Systematics and Ecology, Faculty of Science, University of the Ryukyus, 1 Senbaru,

Nishihara, Okinawa 903-0213, Japan

\section{J. D. Reimer}

Tropical Biosphere Research Center, University of the Ryukyus, 1 Senbaru, Nishihara, Okinawa 903-0213, Japan

\section{S. Shirakashi}

Aquaculture Research Institute, Kindai University, Shirahama 3153, Wakayama 649-2211, Japan

\section{J. Nolan}

University Biomedical Services, University of

Cambridge, Cambridge CB3 0JX, UK 